University of South Carolina

Scholar Commons

2010

\title{
Analysis of Fluvial Suspended Sediment Load Contribution through Anthropocene History to the South Atlantic Bight Coastal Zone, U.S.A.
}

\author{
K McCarney-Castle \\ University of South Carolina - Columbia \\ George Voulgaris \\ University of South Carolina - Columbia, gvoulgaris@geol.sc.edu
}

A J. Kettner

University of Colorado at Boulder

Follow this and additional works at: https://scholarcommons.sc.edu/geol_facpub

Part of the Earth Sciences Commons

\section{Publication Info}

Published in Journal of Geology, Volume 118, Issue 4, 2010, pages 339-416.

McCarney-Castle, K., Voulgaris, G., \& Kettner, A. J. (2010). Analysis of fluvial suspended sediment load contribution through anthropocene history to the South Atlantic Bight Coastal Zone, U.S.A. The Journal of Geology, 118 (4), 399-416.

(C) The Journal of Geology 2010, University of Chicago Press

This Article is brought to you by the Earth, Ocean and Environment, School of the at Scholar Commons. It has been accepted for inclusion in Faculty Publications by an authorized administrator of Scholar Commons. For more information, please contact digres@mailbox.sc.edu. 


\title{
Analysis of Fluvial Suspended Sediment Load Contribution through Anthropocene History to the South Atlantic Bight Coastal Zone, U.S.A.
}

\author{
K. McCarney-Castle, G. Voulgaris, and A. J. Kettner ${ }^{1}$ \\ Coastal Processes and Sediment Dynamics, Department of Earth and Ocean Sciences, \\ University of South Carolina, Columbia, South Carolina 29208, U.S.A. \\ (e-mail: kmccarney@geol.sc.edu)
}

\begin{abstract}
A B S T R A C T
Discerning the effects of anthropogenic activities (i.e., reservoir construction, land use change), as opposed to those of natural processes (i.e., climate variability), on suspended sediment flux has become an increasingly difficult challenge. This contribution presents water and suspended sediment flux from five major watersheds that discharge into the southeastern U.S. Atlantic, a region that is currently considered sediment starved. Three periods of Anthropocene time were defined and evaluated: (1) "pre-European conditions" (1680-1700), (2) "pre-dam conditions" (1905-1925), and (3) "post-dam conditions" (1985-2005). Physical and hydrologic watershed data were used to run a climate-driven hydrological transport numerical model (HydroTrend) to estimate suspended sediment flux for each period. Results indicate that the suspended sediment contribution to the South Atlantic Bight coastal zone increased by up to $145 \%$ as a result of accelerated soil erosion conditions caused by the arrival of European settlers and has since declined by approximately $55 \%$, primarily because of the construction of large reservoirs. This trend suggests a return to preEuropean sediment yields, approximately 100 years after historic peak of soil erosion in the southeastern Piedmont. Our results indicate that variations in sediment yield between time periods are primarily caused by direct anthropogenic forcings, while climate changes over the periods considered have played an insignificant role.
\end{abstract}

\section{Introduction}

Quantification of fluvial sediment transfer to the global oceans is an ongoing scientific endeavor that began more than 50 yr ago (Panin 2004; Walling 2006). Few complete suspended sediment load data sets are available or reliable before 1950, and data often present inconsistencies due to temporal interruptions in data collection and uncontrolled collection techniques (Milliman and Meade 1983). Dependable sediment data are crucial for downstream water quality research because contaminants attached to river-borne sediment particles have become the leading contributor of coastal pollution (EPA 2000). Furthermore, the quantity of sediment reaching the coast affects shoreline stability, which impacts the economies of coastal communities (Sy-

Manuscript received July 11, 2009; accepted February 2, 2010.

${ }^{1}$ Community Surface Dynamics Modeling System, Institute of Arctic and Alpine Research (INSTAAR), University of Colorado, Boulder, Colorado 80309-0450, U.S.A. vitski 2003; Walling and Fang 2003; Vörösmarty et al. 2009). Despite these significant environmental, geomorphic, and economic impacts, less than 10\% of the world's rivers are outfitted with instrumentation to measure sediment flux at the river mouth (Syvitski et al. 2005).

With recent advances in global sediment research and free access to digital terrain models, and in light of declining government-funded sediment-monitoring programs, numerical modeling has become an increasingly useful method to examine sediment movement through large watersheds over time. Currently, fluvial suspended sediment research in most parts of the world is complicated by reservoir retention, land use change, climate change, or a combination of the three that may result in a simultaneous increase and decrease in riverine sediment load (Syvitski 2003). Over the past five decades, approximately 100 billion metric tons $(\mathrm{Bt})$ of sediment, or $30 \%$ of the total potential global flux,

[The Journal of Geology, 2010, volume 118, p. 399-416] @ 2010 by The University of Chicago. All rights reserved. 0022-1376/2010/11804-0004\$15.00. DOI: 10.1086/652658 
has been trapped behind large dams (Vörösmarty et al. 1997; Syvitski et al. 2005), significantly impeding land-ocean sediment transfer (Walling and Fang 2003). For example, in the United States, there are 75,000 dams impounding at least some portion of every single large watershed (Graf 2006); however, human impact (deforestation, land use change) on the land surface is now considered to be an order of magnitude more significant than all "natural" processes combined, thereby increasing rates of sediment erosion and transfer (Wilkinson 2005). Therefore, it is imperative that reservoir entrapment and human impact be incorporated into global sediment transfer and delivery models (Vörösmarty et al. 2003).

The Piedmont region of the eastern United States exhibits sediment yields that are the highest per unit area of any province on the Atlantic coast (Meade 1982), and the watersheds in this area play an integral role in sediment transfer to the southeast Atlantic coastal region. Despite their relatively high yields, the rivers in this region (Altamaha, Savannah, Santee, Pee Dee, and Cape Fear) have no or very limited records of measured suspended sediment load at their mouths. The available data, typically recorded over short periods during the 1970s, indicate a significant decline, when compared to conditions prevalent only $\sim 100$ yr ago, due to the emplacement of large hydroelectric reservoirs, which were built to harness steep gradients and stream power near the fall line (Meade and Trimble 1974; Meade and Parker 1984; Milliman and Meade 1983). Previously published sediment load estimates are documented in a number of reports and papers (Dole and Stabler 1909; Curtis et al. 1973; Milliman and Meade 1983; Meade and Parker 1984; Milliman and Syvitski 1992), and a more recent compilation is found in Milliman and Farnsworth (2005). Our study revisits some of the classic work performed in this region by Dole and Stabler (1909), Trimble (1974), Meade and Trimble (1974), Meade (1982), Meade and Parker (1984), and Phillips (1991), among others.

Quantifying Piedmont riverine sediment transfer over time involves identifying changes in sediment load associated with (i) land use, (ii) dam retention, and (iii) climate (Syvitski et al. 2005; Walling 2006). In this study, we examine three 20-yr periods of Anthropocene time by considering these changes in five large southeastern United States rivers. These periods include the years (i) 1985-2005, representing current conditions, (ii) 1905-1925, representing conditions of accelerated erosion before dam construction, and (iii) 1680-1700, representing conditions before the arrival of European settlers.
We implement a hydrologic model that has thus far been applied over long time periods and primarily to rivers possessing globally significant sediment loads (Kettner et al. 2007; Kettner and Syvitski 2008b). This study represents the first application of this model over short time periods (decadal) in the southeastern United States and provides insight into the usefulness of such an approach for future research in smaller southeastern watersheds with no recorded sediment data. The results of this study provide a moving snapshot of sediment transfer to a region of the country that is currently considered sediment starved (Patchineelam et al. 1999). Pre-European results shed light on "baseline" conditions that may be useful in restoration projects (Pasternack et al. 2000). Specific interest is placed on modification of sediment transfer through resevoir retention and on how sediment loads may be trending toward pre-European yields after nearly half a century of dam construction. Finally, we briefly discuss how this trend may have coastal-zone implications.

\section{Regional Setting}

The southeastern United States consists of three major physiographic provinces: the Blue Ridge Mountains, the Piedmont, and the Coastal Plain (fig. 1b). The major river systems that flow through these regions and discharge into the South Atlantic Bight coastal zone are the Pee Dee, the Santee, the Savannah, the Altamaha, the Cape Fear, and the St. John's (fig. 1; Morton and Miller 2005). The St. John's River in Florida contributes no appreciable sediment and does not have its headwaters in the Piedmont region and is therefore excluded from this study. Basin characteristics of the remaining five watersheds are listed in table 1. The hypsometric curves (basin area vs. elevation) of each basin in terms of absolute area and normalized by the total area are shown in figures $2 a$ and $2 b$, respectively, and the approximate location of the fall line (elevation $45-116 \mathrm{~m}$ ) is also indicated.

Piedmont and Coastal Plain of the Southeast. The Piedmont region is characterized by undulating hills with broad, semidissected valleys and is separated from the Coastal Plain by a southwest-trending fall line (fig. $1 b$ ). The region is primarily tectonically inactive and consists of medium-grade metamorphic rocks with thick saprolite units (15$30 \mathrm{~m}$ ) overlaying fractured bedrock in some areas. Rainfall and snowfall average 900-1200 and 2-75 $\mathrm{mm} / \mathrm{yr}$, respectively (http://www7.ncdc.noaa.gov/ IPS/cd/cd.html).

The Coastal Plain consists of a relatively flat, 


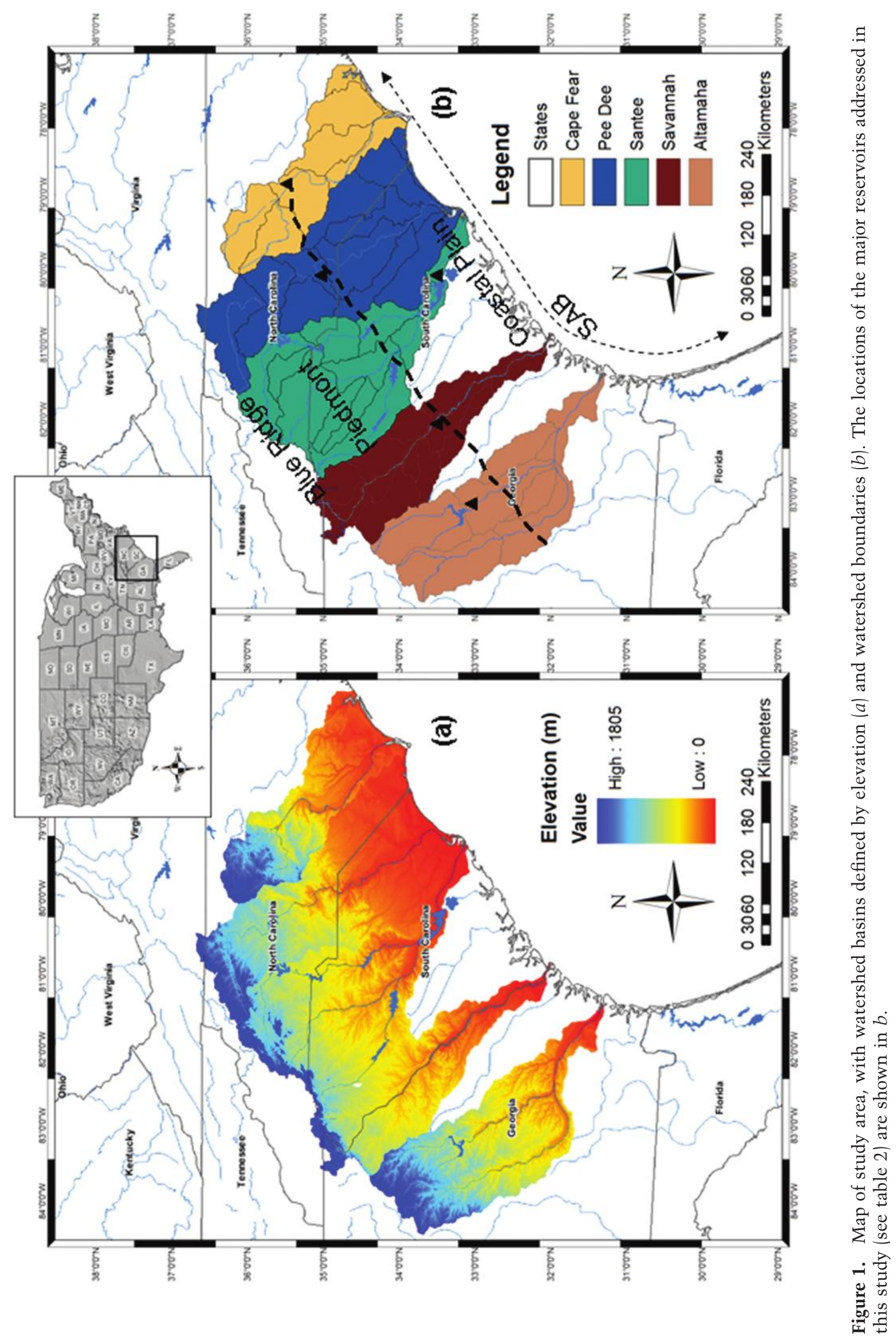


Table 1. Watershed Characteristics of Individual Basins

\begin{tabular}{|c|c|c|c|c|c|c|c|}
\hline Basin & $\begin{array}{l}\text { Area } \\
\left(\mathrm{km}^{2}\right)\end{array}$ & $\begin{array}{c}\text { Maximum } \\
\text { elevation } \\
(\mathrm{m})\end{array}$ & $\begin{array}{l}\text { Length } \\
\quad(\mathrm{km})\end{array}$ & $\begin{array}{l}\text { Mouth gradient } \\
\qquad(\mathrm{m} / \mathrm{m})\end{array}$ & Terminus & $\begin{array}{l}\text { Lat/Long } \\
\quad \text { (deg) }\end{array}$ & $\begin{array}{c}\text { Annual flow } \\
\qquad\left(\mathrm{m}^{3} / \mathrm{s}\right)\end{array}$ \\
\hline Altamaha & 36,590 & 513 & 575 & $1.20 \mathrm{E}-04$ & Altamaha Sound & $31.385,-81.546$ & 380 \\
\hline Savannah & 27,153 & 1538 & 560 & $1.30 \mathrm{E}-04$ & Savannah Estuary & $32.035,-80.895$ & 330 \\
\hline Santee & 37,013 & 1805 & 500 & $5.67 \mathrm{E}-04$ & Atlantic Ocean & $33.172,-79.295$ & 400 \\
\hline Pee Dee & 47,560 & 1256 & 625 & $3.95 \mathrm{E}-05$ & Winyah Bay & $33.377,-79.246$ & 275 \\
\hline Cape Fear & 23,631 & 324 & 400 & $2.11 \mathrm{E}-05$ & Cape Fear Estuary & $34.176,-77.957$ & 200 \\
\hline
\end{tabular}

Source. Water discharge data from Global Runoff Data Centre (http://www.bafg.de/cln_007/GRDC/EN/Home/ homepage_node.html?_nnn = true).

seaward-thickening wedge of unconsolidated Cenozoic sedimentary rock (Hayes 1994). The Coastal Plain of the southeast typically receives $500-800$ $\mathrm{mm}$ of rain annually, although rainfall can sometimes exceed $1800 \mathrm{~mm}$, and elevation ranges from 0 to $25 \mathrm{~m}$ (http://www7.ncdc.noaa.gov/IPS/cd/ cd.html). The South Atlantic Bight, or Georgia Bight, is a $1200-\mathrm{km}$-long, tectonically inactive, lowlying section of coastline characterized by estuaries, barrier islands, capes, and tidal inlets, extending from Cape Hatteras, North Carolina, to Cape Canaveral, Florida (Hayes 1994; Morton and Miller 2005).

Anthropogenic Impact in the Southeast. Sediment discharge from southeastern river systems has varied over time because of human impact (Meade and Trimble 1974; Trimble 1974; Milliman and Meade 1983; Phillips 1991). European settlement began in 1700 and continued in a southwestward trend from Virginia to Alabama until occupation was complete around 1830 (Trimble 1974). The arrival of settlers and the associated deforestation caused accelerated soil erosion throughout the region. The highest rates of soil erosion occurred from 1860 to 1930, with peak erosive conditions occurring from 1900 to 1920 (Meade and Trimble 1974). Trimble (1974) estimated that during this time, $190 \mathrm{~mm}$ of soil was eroded from the Piedmont area of Georgia, 240 $\mathrm{mm}$ from South Carolina, and $140 \mathrm{~mm}$ from North Carolina/Virginia.

Around 1925, dam construction had begun in the southeast, and a corresponding decrease in sediment load was observed in some fluvial systems (Trimble 1974). More recently, Syvitski et al. (2005) noted that although global soil erosion is accelerating, sediment discharge to the coasts is declining because of reservoir retention, resulting in coastal land loss. The direct link between upstream damming and downstream (coastal) sediment starvation has been documented in a number of studies (e.g., Willis and Griggs 2003; Liquete et al. 2004), and while the southeast coast has always received the majority of its sediment from nearshore sand shoals and eroded beach material, it is believed that it was not uncommon for rivers to deliver sediment, even sand, directly to the coast before reservoirs were constructed (Hayes 1994; Morton and Miller 2005).

\section{Methods}

The 20-yr period for post-dam (1985-2005) model runs was constrained by the conclusion of the dambuilding era and the present day. The emplacement of large dams halted largely in the mid-1970s, and because erosion downstream of a dam is typically most severe in the decade immediately following dam construction (Gregory 2006), although duration and distance downstream are extremely variable between systems (Williams and Wolman 1984), we did not want to extend the post-dam study to before 1985, as this would have biased our results toward nontypical conditions applicable only for the period immediately following dam construction. Therefore, we chose the period 19852005 to be representative of the post-dam period. For consistency, we also ran our pre-dam (19051925) simulations over a 20 -yr period representing peak erosive conditions in the southeast (Meade and Trimble 1974). The 20 -yr period for pre-European simulations (1680-1700) was chosen to capture conditions immediately before the arrival of settlers, which began in 1700; however, any 20-yr period before 1700 would generate similar results.

\section{Numerical Model}

HydroTrend 3.0, a climate-driven hydrological transport model (Kettner and Syvitski 2008a), is applied in this study to determine the spatial and temporal sediment flux changes for the five selected watersheds (table 1). Two main input data sets are required to operate the model: hypsometric data and physical watershed data (table 2). The model 

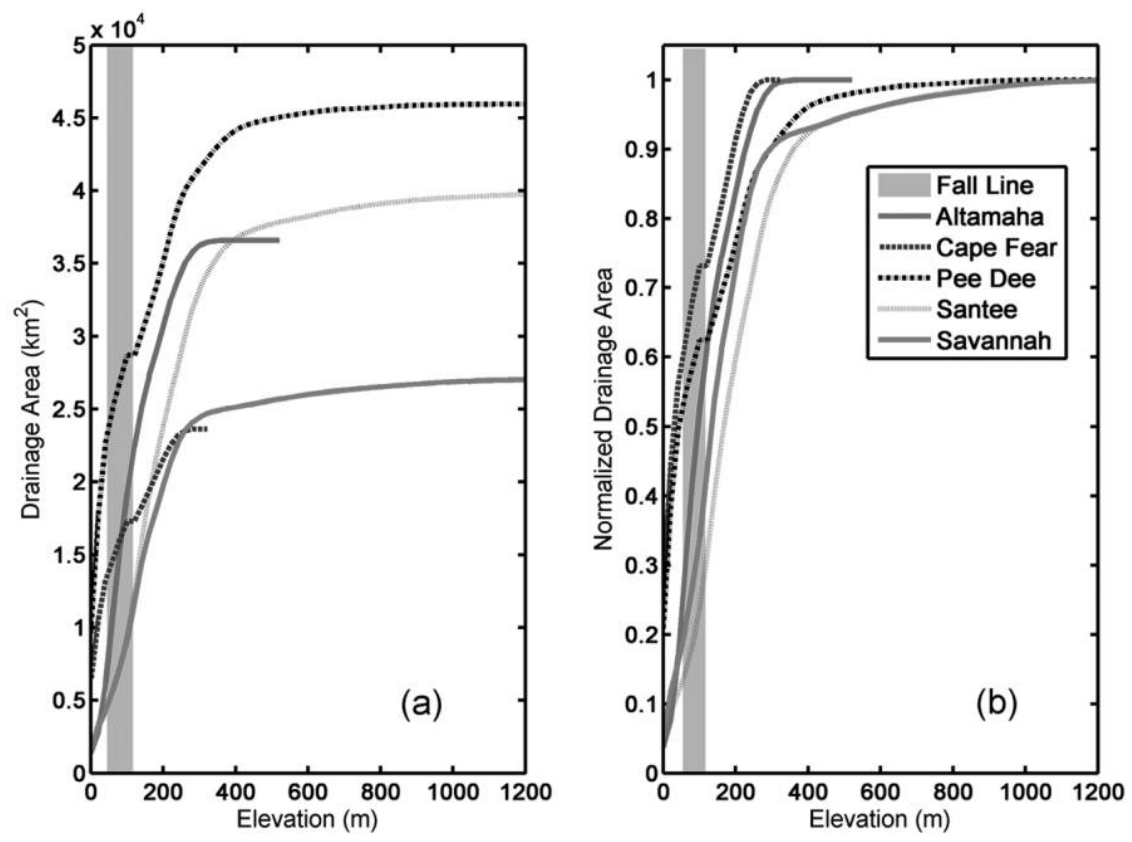

Figure 2. Absolute $(a)$ and normalized $(b)$ hypsometric curves for the five watersheds examined in this study.

utilizes information on climate, morphology, geology, human impact, and soil characteristics within a watershed to estimate time series of water discharge and sediment load at the river mouth, with a minimum time step of $1 \mathrm{~d}$. On the basis of integrated empirical equations (see Kettner and Syvitski 2008a), the model converts yearly and monthly climate input statistics (mean and standard deviation of precipitation and temperature) into daily precipitation (Syvitski et al. 1998). HydroTrend has been successfully applied in studies of the Eel River in California (Syvitski and Morehead 1999|, the Lanyang Watershed on Taiwan (Syvitski et al. 2004), the Waipaoa River in New Zealand (Kettner et al. 2007), and the Magdalena River in Colombia (Kettner et al. 2010). The model is described in detail in Syvitski et al. (1998) and Kettner and Syvitski (2008a), and only a brief description of the most significant elements is presented here.

Water Discharge. The daily water discharge $(Q$, in $\mathrm{m}^{3} / \mathrm{s}$ ) calculations are based on a classic water balance model that incorporates the effects of rain $(\mathrm{r})$, snow $(\mathrm{n})$ and ice melt (ice), groundwater discharge (gr), and evapotranspiration (eva) within the watershed:

$$
Q=Q_{\mathrm{r}}+Q_{\mathrm{n}}+Q_{\mathrm{ice}} \pm Q_{\mathrm{gr}}-Q_{\mathrm{eva}} .
$$

Sediment Transport. The daily suspended sedi- ment discharge $\left(\mathrm{Qs}_{[i]}\right.$, in $\left.\mathrm{kg} / \mathrm{s}\right)$ is simulated from the long-term averaged sediment transport $\left(\overline{\mathrm{Qs}_{\mathrm{T}}}\right)$ by means of a methodology (Psi model), described in Morehead et al. (2003), that utilizes a derivative of the standard empirical rating equation $\left(\mathrm{Q} s=a Q^{C}\right)$.

$$
\left(\frac{\overline{\mathrm{Qs}}_{[i]}}{\overline{\mathrm{Qs}}_{\mathrm{T}}}\right)=\psi_{[i]} f\left(\frac{\mathrm{Q}_{[i]}}{\overline{\mathrm{Q}}}\right)^{C_{[a]}},
$$

where $\overline{\mathrm{Qs}_{\mathrm{T}}}$ is the total long-term average suspended sediment discharge (in $\mathrm{kg} / \mathrm{s}$ ), $\bar{Q}$ is the long-term average water discharge $\left(\right.$ in $\left.\mathrm{m}^{3} / \mathrm{s}\right), Q_{[i]}$ is the daily discharge $\left(\right.$ in $\left.^{3} / \mathrm{s}\right), \psi_{[i]}$ is a random, lognormal variable with a mean of 1 and a standard deviation that is a function of water discharge (Morehead et al. 2003; Kettner and Syvitski 2008a), $C_{(a)}$ is the rating exponent (normal random variable), varying over a 1-yr time step, and $f$ is a constant of proportionality defined by

$$
f=\frac{\left(\sum_{i=1}^{n} \mathrm{Qs}_{[i]} / \overline{\mathrm{Qs}_{\mathrm{T}}}\right)}{n},
$$

where $n$ is the number of days over the model run. Unlike the standard rating curve, the Psi model is able to reproduce the statistics of the variability (intra- and interannual) commonly seen in rivers (Morehead et al. 2003; Kettner and Syvitski 2008a). This is achieved by assuming that the coefficient $C$ of the rating curve (see eq. [2]) varies annually 
Table 2. Input Parameters for Hydrologic Model HydroTrend, Source, and Example of a Typical Southeastern Watershed (Altamaha)

\begin{tabular}{|c|c|c|}
\hline Input parameter & Source & $\begin{array}{l}\text { Example: Altamaha } \\
\text { watershed }\end{array}$ \\
\hline Title of model run & User supplied & Altamaha Watershed \\
\hline Output location & User supplied & C://output \\
\hline Start year, run time $(\mathrm{yr})$, and frequency ${ }^{\mathrm{a}}$ & User supplied & $1985,20, \mathrm{M}$ \\
\hline $\begin{array}{l}\text { Yearly temperature: start, change/yr, } \\
\text { SD }\left({ }^{\circ} \mathrm{C}\right)\end{array}$ & Calculated from climate data & $18.15, .0,2.6$ \\
\hline $\begin{array}{l}\text { Yearly precipitation: start, change/yr, } \\
\text { SD (m/yr) } \\
\text { Rain mass balance coefficient, distribution }\end{array}$ & Calculated from climate data & $1.17, .0, .5$ \\
\hline exponent, range & Calculated from climate data & $1,1.6,7$ \\
\hline Constant baseflow $\left(\mathrm{m}^{3} / \mathrm{s}\right)$ & $\begin{array}{l}\text { Hydrograph separation (USGS gauge: } \\
\text { http://waterdata.usgs.gov/usa/nwis/ } \\
\text { sw) }\end{array}$ & \\
\hline \multicolumn{3}{|l|}{$\begin{array}{l}\text { Monthly climate variables: average } \\
\text { temperature with SD }\left({ }^{\circ} \mathrm{C}\right) \text {; average } \\
\text { precipitation with SD }(\mathrm{mm}) \text { : }\end{array}$} \\
\hline January & Climate data & $7.84,4.5 ; 115.41,13$ \\
\hline February & Climate data & $10.02,3.5 ; 102.67,16$ \\
\hline March & Climate data & $13.65,3.7 ; 120.11,15$ \\
\hline April & Climate data & $17.39,3.88 ; 71.72,10$ \\
\hline May & Climate data & $22.04,2.78 ; 72.94,10$ \\
\hline June & Climate data & $25.60,1.53 ; 120.38,15$ \\
\hline July (similarly for August-December) & Climate data & $27.51,1.30 ; 126.0,17$ \\
\hline Lapse rate $\left({ }^{\circ} \mathrm{C} / \mathrm{km}\right)$ & http://www.theweatherprediction.com & 6.5 \\
\hline $\begin{array}{l}\text { Glacier equilibrium line altitude, } \\
\text { change/yr (m) }\end{array}$ & Not applicable to this study & $10,000,0$ \\
\hline Dry precipitation evaporation fraction & Not applicable to this study & \\
\hline $\begin{array}{l}\text { Canopy interception } \alpha_{\mathrm{g}}(-.1[\mathrm{~mm} / \mathrm{d}]), \\
\beta_{\mathrm{g}}(.85)\end{array}$ & $\begin{array}{l}\text { See Syvitski et al. } 1998 \text { for explanation } \\
\text { of variables }\end{array}$ & $-.1, .85$ \\
\hline $\begin{array}{l}\text { Evapotranspiration } \alpha_{\text {gwe }} \text { (common } 10 \\
[\mathrm{~mm} / \mathrm{d}]), \beta_{\text {gwe }}(\text { common } 1)\end{array}$ & $\begin{array}{l}\text { See Syvitski et al. 1998; data from } \\
\text { Purvis } 2006\end{array}$ & 10,1 \\
\hline Delta plain gradient $(\mathrm{m} / \mathrm{m})$ & Calculated in RiverTools ${ }^{\mathrm{b}}$ & $1.20 \mathrm{E}-04$ \\
\hline River basin length $(\mathrm{km})$ & Calculated in RiverTools & 575 \\
\hline $\begin{array}{l}\text { Reservoir volume }\left(\mathrm{km}^{3}\right) \text {; drainage area }\left(\mathrm{km}^{2}\right) \\
\text { or altitude }(\mathrm{m})\end{array}$ & $\begin{array}{l}\text { National Inventory of Dams Database } \\
\text { (http:crunch.tec.army.mil/nidpublic/ } \\
\text { webpages/nid.cfm) }\end{array}$ & $.411 ; \mathrm{d} 7536^{\mathrm{c}}$ \\
\hline Mouth velocity coefficient, exponent & Calculated (Leopold and Maddock 1953) & $.26, .1$ \\
\hline Mouth width coefficient, exponent & Calculated (Leopold and Maddock 1953) & $9.29, .5$ \\
\hline Average river velocity $(\mathrm{m} / \mathrm{s})$ & Averaged from USGS gauge & .9 \\
\hline $\begin{array}{l}\text { Maximum and minimum groundwater } \\
\text { storage }\left(\mathrm{m}^{3}\right)\end{array}$ & & $7.32 \mathrm{E}+08,3.66 \mathrm{E}+07$ \\
\hline Initial groundwater storage $\left(\mathrm{m}^{3}\right)$ & Calculated using basin area, soil depth & $\begin{array}{l}1.02 \mathrm{E}+\mathrm{U}, 0.00 \mathrm{E}+\mathrm{U} / \\
3.66 \mathrm{E}+07\end{array}$ \\
\hline Subsurface storm flow $\left(\mathrm{m}^{3} / \mathrm{s}\right)$ & Estimated using basin area, soil depth & 100 \\
\hline Hydraulic conductivity (mm/d) & Estimated from predominant soil type & 300 \\
\hline Longitude/latitude of mouth (deg) & Geographic information system & $-81.5465,31.3851$ \\
\hline Lithologic factor & $\begin{array}{l}\text { USGS geologic maps; Syvitski and } \\
\text { Milliman } 2007\end{array}$ & .8 \\
\hline Anthropogenic factor & $\begin{array}{l}\text { Population density; Syvitski and } \\
\text { Milliman } 2007\end{array}$ & 1 \\
\hline
\end{tabular}

a Frequency categories are daily (D), monthly $(\mathrm{M})$, yearly $(\mathrm{Y})$, and seasonal.

b RiverTools is a topographic and river network analysis software package (http://rivix.com/).

c "d" indicates "drainage area." 
Table 3. Rivers and Respective Reservoirs Considered in This Study

\begin{tabular}{llccc}
\hline River & Reservoir name & Year & $\begin{array}{c}\text { Drainage area } \\
\left(\mathrm{km}^{2}\right)\end{array}$ & $\begin{array}{c}\text { Volume capacity } \\
\left(\mathrm{km}^{3}\right)\end{array}$ \\
\hline Altamaha & Sinclair Dam & 1953 & 7536 & .411 \\
Savannah & Strom Thurmond & 1952 & 15,913 & 3.57 \\
Santee & Santee Dam & 1942 & 38,058 & 1.52 \\
Pee Dee & Lake Tillery & 1928 & 11,913 & .206 \\
Cape Fear & B. Everett Jordan & 1974 & 4377 & .265 \\
\hline
\end{tabular}

Source. National Inventory of Dams (http//:crunch.tec.army.mil/nidpublic/webpages/nid.cfm).

and that the variation follows a normal distribution with a mean $(E)$ and standard deviation $(\sigma)$ that depend on temperature $(T)$, relief $(R)$, water discharge $(\bar{Q})$, and long-term sediment transport $\left(\overline{\mathrm{Qs}_{\mathrm{T}}}\right)$ :

$$
\begin{aligned}
& E(C)=1.4-0.025 T+0.00013 R+0.145 \ln \overline{\mathrm{Qs}_{\mathrm{T}}} \\
& \sigma(C)=0.17+0.0000183 \overline{\mathrm{Q}} .
\end{aligned}
$$

The B Parameter. HydroTrend also incorporates lithology, reservoir retention, and human impact $\left(L, T_{\mathrm{E}}\right.$, and $E_{\mathrm{h}}$, respectively) in a parameter $B$, defined as

$$
B=I \times L \times\left(1-T_{\mathrm{E}}\right) \times E_{\mathrm{h}}
$$

where $I$ accounts for glacier erosion. The long-term sediment load is then determined by the BQART equation,

$$
\overline{\mathrm{Qs}_{\mathrm{T}}}=w B \overline{\mathrm{Q}}^{0.31} A^{0.5} R T,
$$

where $\omega$ is a coefficient of proportionality $(0.02 \mathrm{~kg} /$ $\left.\mathrm{s} / \mathrm{km} /{ }^{\circ} \mathrm{C}\right)$. These relationships were derived from an extensive database of rivers covering $63 \%$ of the global surface and are described in detail in Syvitski and Milliman (2007) and Kettner and Syvitski $(2008 a)$. The parameters that define the $B$ factor are discussed briefly below.

Lithology. The influence of lithology $(L)$ on sediment flux is determined by a numerical index ranging from soft lithology $(L=3$; e.g., loess, sand dunes $)$ to hard lithology $(L=0.5$; e.g., metamorphic rock; Syvitski and Milliman 2007). This type of scale is used to classify rock types on the basis of resistance to mechanical weathering (Hadley et al. 1985; Ludwig and Probst 1998). In our study, an average $L$ value for each watershed was derived from geologic maps and varied slightly between watersheds, depending on the percentage of the individual basin area within metamorphic terrain (Syvitski and Milliman 2007).

Anthropogenic Influence $\left(\mathrm{E}_{h}\right)$. Socioeconomic conditions, land use change, and population density are the main factors driving anthropogenic sediment yield (Syvitski and Milliman 2007). The HydroTrend model applies an "a priori method"
(Kettner and Syvitski 2008a) that defines the parameters of $E_{\mathrm{h}}$ by population density and gross national product (GNP) per capita (Syvitski and Milliman 2007). This value ranges from $E_{\mathrm{h}}=0.3$ (high population density and high GNP/capita), which represents low active erosion rates, to $E_{\mathrm{h}}=2$ (high population density with low GNP/capita), which represents high rates of erosion (Syvitski and Milliman 2007). Data from current polls and surveys (http://www.census.gov; http://www.bea.gov// were used as input for present-day $E_{\mathrm{h}}$ conditions, and values vary slightly from basin to basin (average $E_{\mathrm{h}}=1$ ). Representation of pre-dam conditions, when human-induced erosion was at its peak, was achieved after correlation of the $E_{\mathrm{h}}$ factor with degree of erosive land use, as predicted by Trimble $\left(1974 ; E_{\mathrm{h}}>1\right)$. For pre-European simulations, the $E_{\mathrm{h}}$ factor was decreased to the lowest practical increment, because there was minor human impact in the southeast at that time $\left(E_{\mathrm{h}}=0.5\right)$.

Trapping Efficiency. Permanent sediment storage is incorporated by use of the trapping efficiency of a reservoir $\left(T_{\mathrm{E}}\right)$, which is calculated by applying the Brown (1943) equation for smaller reservoirs and the Brune (1953) and modified Vörösmarty et al. (1997) equations for reservoirs larger than 0.5 $\mathrm{km}^{3}$. The farthest-downstream reservoir on each river and its dimensions (table 3) are used in postdam simulations to represent entire-basin impoundment. This proves to be a reliable method because all reservoirs have trapping efficiencies near $100 \%$, although this rate will decline in the future as reservoirs fill with sediment. Storage sites within Piedmont valleys and on flood plains of the Coastal Plain are considered temporary storage sites, and recently deposited sediment, as well as stored legacy sediment, has the potential to be offset by sediment that moves out of storage or by new sediment incorporated through bank erosion (Milliman and Meade 1983; Williams and Wolman 1984; Kondolf 1997; Walling and Fang 2003; Phillips and Slattery 2006; James, forthcoming). Because of this "moving-target" effect, temporary storage is not parameterized in the model (Kettner 


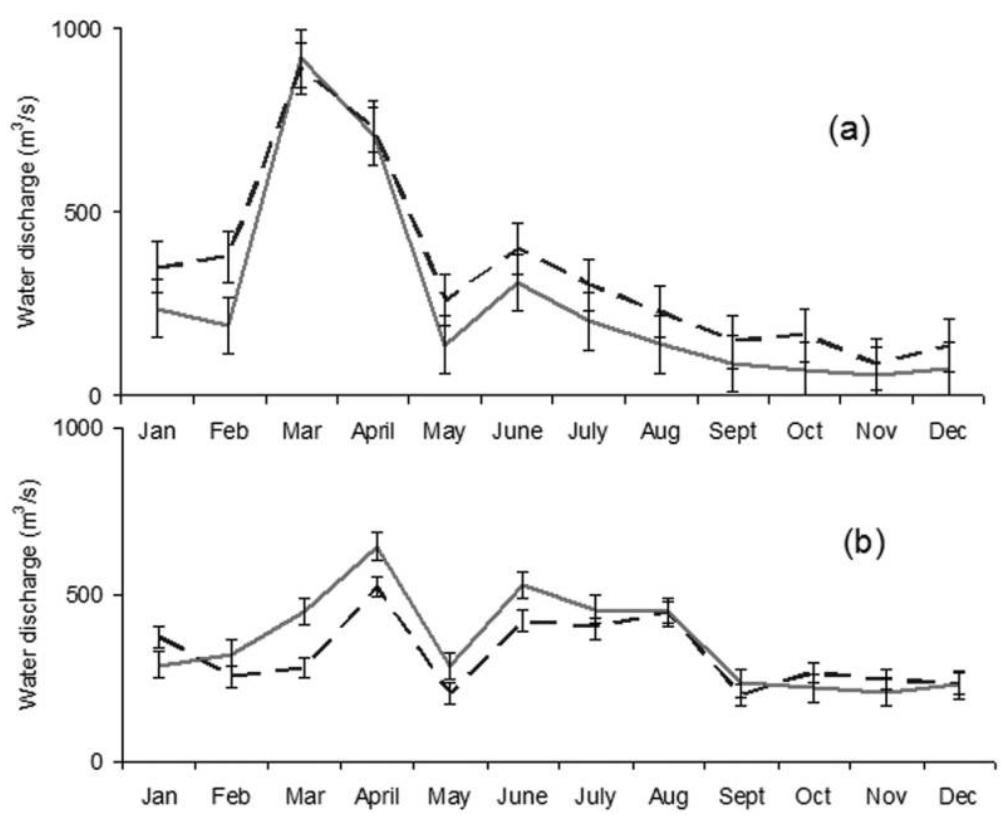

Figure 3. Observed (solid line) versus simulated (dashed line) monthly average water discharge $\left(\mathrm{m}^{3} / \mathrm{s}\right.$ ) from the Altamaha River for the year $2001(a)$ and the Savannah River for the year $2005(b)$. Error bars indicate variability \pm $1 \mathrm{SD}$ for the year.

and Syvitski 2008a). In addition, the ability of reservoirs to reduce flood peaks is incorporated into the HydroTrend model. A water discharge lag time is added, determined by the volume of the reservoir. Assumptions are made regarding the time lag: small lakes and reservoirs $\left(<0.5 \mathrm{~km}^{3}\right)$ have a $1-\mathrm{d}$ delay in which the water is slowly released, and larger lakes and reservoirs $\left(0.5 \mathrm{~km}^{3}\right)$ have a 2-d window in which the water is slowly released, thereby minimizing peak floods.

Sensitivity and Error. According to Syvitski and Milliman (2007) and a database of 488 rivers, which covers $63 \%$ of the worlds' surface, suspended sediment load is moderately dependent on lithology $\left(R^{2}=0.14\right)$ and human-induced soil erosion $\left(R^{2}=0.13\right)$ and strongly dependent on area $\left(R^{2}=\right.$ $0.58)$, relief $\left(R^{2}=0.40\right)$, and water discharge $\left(R^{2}=0.67\right)$. Within a typical watershed, spatial variations in physical parameters can introduce uncertainties in boundary conditions used as numerical input (Overeem et al. 2005). A series of sensitivity tests was carried out to analyze this range of uncertainties. Six variables /canopy interception, evapotranspiration, subsurface storm flow, groundwater pool, anthropogenic impact, and lithology) were considered within individual watersheds over each time period, resulting in 90 sensitivity tests. An error propagation analysis based on the results of the sensitivity tests was carried out on the latter two variables (factors in $B$ ), which could significantly affect sediment load results (Syvitski and Milliman 2007). The significances of the $E_{\mathrm{h}}$ and $L$ parameters were given the same weight throughout the error propagation analysis, and realistic maximum and minimum values were applied to each significant parameter over individual simulation runs. Results are presented in "Results." Confidence was high regarding the data used to generate watershed morphology and climate, so these parameters were not incorporated into uncertainty analyses.

Validation. Twenty years of monthly average USGS stream gauge water data (http://waterdata .usgs.gov/usa/nwis/sw) were used from each basin in order to validate the model. We also used shortterm data $(12 \mathrm{mo})$ to confirm HydroTrend's ability to reproduce monthly discharge patterns by simulating randomly selected years (2001 and 2005). The results of the short-term analysis are shown in figure 3 for the Altamaha (gauge 02226000) and Savannah River basins (gauge 02198500).

\section{Climate}

USGS-derived watershed boundaries were applied to 30-m-resolution digital elevation models to delineate and extract the five basins. Daily mean air temperature and precipitation data were obtained 
from the Climatological Data Publications data set at NOAA Satellite and Information Service (NESDIS) and the National Climatic Data Center (NCDC; http://www7.ncdc.noaa.gov/IPS/cd/cd.html). Monthly averages and standard deviations were derived for two periods of time for each of the five basins: (1) 1905-1925, referred to as the "pre-dam" period, which represents conditions under accelerated erosion, and (2) 1985-2005, referred to as the "post-dam" period, which represents current conditions. A representative number of observation stations $(n=30)$ were used to determine basinwide climate for both time periods through spatial interpolation and averaging.

\section{Results}

All simulated and observed mean annual water discharge $\left(\mathrm{m}^{3} / \mathrm{s}\right)$, sediment loads $\left(10^{6} \mathrm{t} / \mathrm{yr}\right.$, or $\left.\mathrm{Mt} / \mathrm{yr}\right)$, and sediment yields per basin area $\left(\mathrm{t} / \mathrm{km}^{2} / \mathrm{yr}\right)$ are provided in table 4 and are discussed in the following sections.

Climate Trends. Temperature and precipitation changes influence patterns of fluvial suspended sediment flux in rivers (Fournier 1960; Jansen and Painter 1974; Farnsworth and Milliman 2003). Figure 4 compares monthly climate data (precipitation and temperature) over each basin for post-dam (1985-2005) and pre-dam (1905-1925) conditions. Results indicate that the climate today is markedly similar to that of $100 \mathrm{yr}$ ago. While changes in quantity, intensity, and timing of precipitation would affect discharge, not enough variation was observed between the data sets to suggest that climate was the main driver altering suspended sediment load between the two time periods (fig. 4). In order to isolate the climate influence, we carried out a simulation of pre-dam conditions, using post-dam climate for one river basin (Altamaha). The difference in suspended sediment flux was negligible $<2.0 \mathrm{~kg} /$ s, i.e., $1.3 \%$ ) over the 20 -yr period, further confirming that climate was not a significant driver of changes in sediment concentration over the century. Overall, mean annual rainfall over the past two decades is slightly higher $(56 \mathrm{~mm})$ than it was 100 years ago. Temperatures between the two periods vary by less than $0.2^{\circ} \mathrm{C}$, on average, and are slightly higher today in the majority of the watersheds (by $<0.13^{\circ} \mathrm{C}$ ). Since no observed records of climate conditions for pre-European conditions (1680-1700) exist, pre-dam climate data were extrapolated backward to represent this period. We acknowledge that there may be a marginal degree of error in this approach; however, alternate forms of data (i.e., reconstructed climate data; Stahle and Cleaveland 1992) are typically averaged across large areas (statewide), thereby incorporating anomalous values.

Water and Sediment Discharge. Simulated suspended sediment flux at the river mouth represents

Table 4. Simulated Mean Annual Water and Suspended Sediment Results for Five Watersheds of the Southeastern United States

\begin{tabular}{|c|c|c|c|c|c|}
\hline River, time period & $\begin{array}{c}\text { Simulated flow } \\
\left(\mathrm{m}^{3} / \mathrm{s}\right)\end{array}$ & $\begin{array}{c}\text { Observed flow } \\
\left(\mathrm{m}^{3} / \mathrm{s}\right)\end{array}$ & $\begin{array}{c}\text { Simulated load } \\
(\mathrm{Mt} / \mathrm{yr})\end{array}$ & $\begin{array}{l}\text { Published load } \\
\text { (Mt/yr) }\end{array}$ & $\begin{array}{c}\text { Simulated yield } \\
\left(\mathrm{t} / \mathrm{km}^{2} / \mathrm{yr}\right)\end{array}$ \\
\hline Altamaha & & 〜380 (1931-2006) & & & \\
\hline Pre-European & 365 & & $.9 \pm .5$ & $\mathrm{n} / \mathrm{a}$ & $24.0 \pm 5.6$ \\
\hline Pre-dam & 388 & & $2.3 \pm .5$ & 2.5 & $62.6 \pm 13.2$ \\
\hline Post-dam & 369 & & $1.5 \pm .2$ & $\sim 1$ & $40.4 \pm 5.5$ \\
\hline Savannah & & 〜33 (1929-2006) & & & \\
\hline Pre-European & 329 & & $1.4 \pm .31$ & $\mathrm{n} / \mathrm{a}$ & $50 \pm 9.0$ \\
\hline Pre-dam & 314 & & $3.5 \pm 1.03$ & 2.8 & $128 \pm 38.3$ \\
\hline Post-dam & 316 & & $1.1 \pm .24$ & $\sim 1$ & $43.5 \pm 5.5$ \\
\hline Santee & & 〜 400 (1929-2006) & & & \\
\hline Pre-European & 404 & & $2.24 \pm .97$ & $\mathrm{n} / \mathrm{a}$ & $56.3 \pm 24.4$ \\
\hline Pre-dam & 409 & & $5.85 \pm 1.7$ & $\mathrm{n} / \mathrm{a}$ & $147 \pm 44.1$ \\
\hline Post-dam & 412 & & $.81 \pm .1$ & .86 & $20.2 \pm 2.51$ \\
\hline Pee Dee & & 〜275 (1938-2006) & & & \\
\hline Pre-European & 339 & & $1.44 \pm .3$ & $\mathrm{n} / \mathrm{a}$ & $30.4 \pm 7.5$ \\
\hline Pre-dam & 364 & & $2.90 \pm .84$ & .86 & $62.1 \pm 17$ \\
\hline Post-dam & 382 & & $1.45 \pm .3$ & .50 & $30.5 \pm 6.5$ \\
\hline Cape Fear & & 〜200 (1969-2004) & & & \\
\hline Pre-European & 234 & & $.23 \pm .07$ & $\mathrm{n} / \mathrm{a}$ & $9.2 \pm 2.7$ \\
\hline Pre-dam & 227 & & $.54 \pm .14$ & $\mathrm{n} / \mathrm{a}$ & $21.9 \pm 5.1$ \\
\hline Post-dam & 210 & & $.37 \pm .06$ & .29 & $15.1 \pm 2.3$ \\
\hline
\end{tabular}

Note. $\mathrm{n} / \mathrm{a}=$ not available.

Sources. Published sediment loads from Milliman and Farnsworth (2005); observed water discharge from USGS water data (http://waterdata.usgs.gov/usa/nwis/sw). 

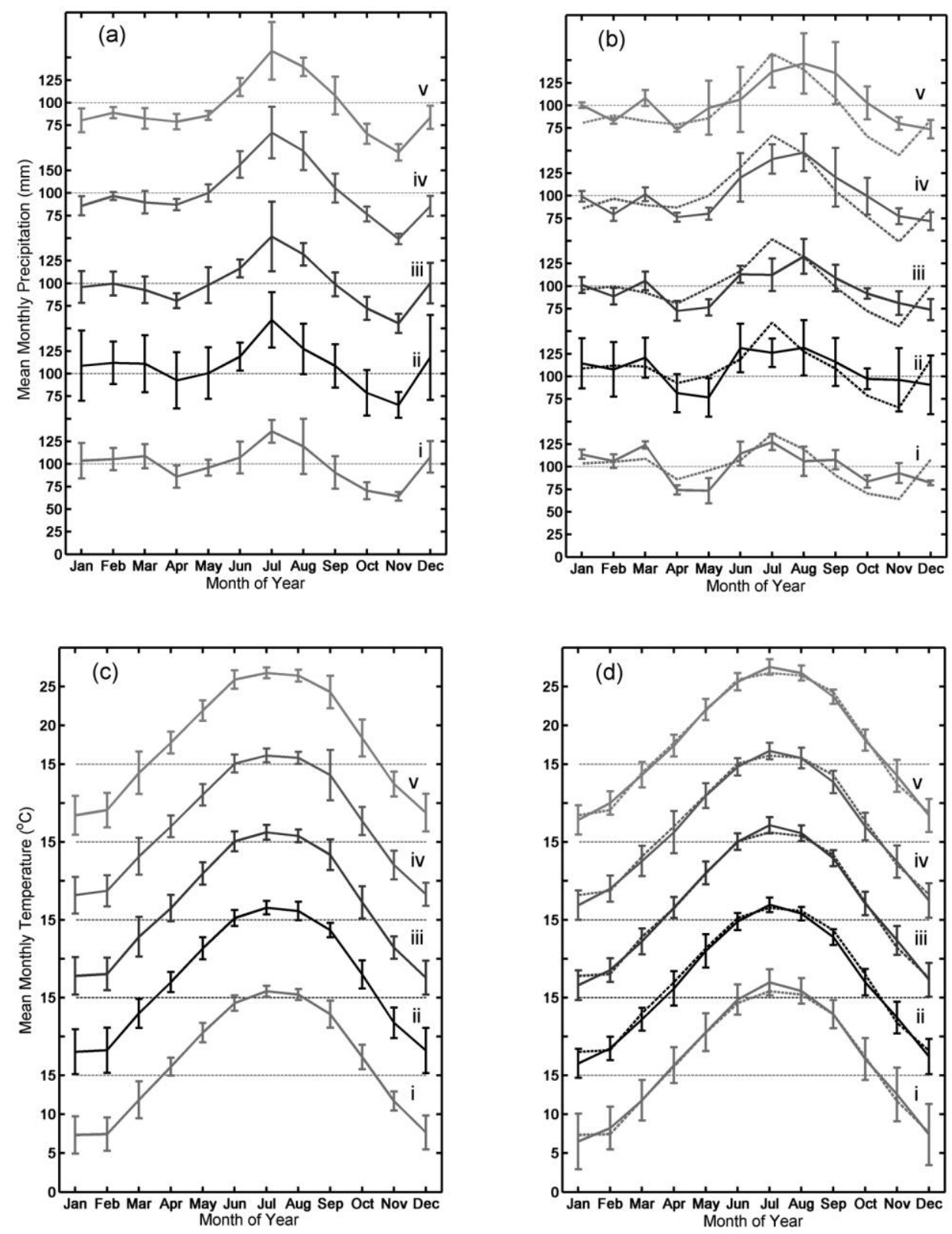

Figure 4. Monthly precipitation $(a, b)$ and temperature $(c, d)$ data $( \pm 1 \mathrm{SD})$ for the five basins of the study area: Cape Fear (i), Pee Dee (ii), Santee (iii), Savannah (iv), and Altamaha (v). Plots $a$ and $c$ represent pre-dam data (1905-1925); $b$ and $d$ represent post-dam data (1985-2005). For comparison, pre-dam data are shown as dashed lines in $b$ and $d$.

the sediment load reaching the area just upstream of the estuary (i.e., the coastal zone). The simulated monthly sediment and water discharges are plotted with observed precipitation for each basin over 20 yr (fig. 5). Simulated suspended sediment trends closely relate to modeled water discharge (average $R^{2}$ of 0.651 , which is typical for Piedmont rivers (Meade 1982; Meade et al. 1990). Scatter plots in figure 6 show the correlation of simulated monthly average sediment flux $(\mathrm{kg} / \mathrm{s})$ with the corresponding monthly average water discharge $\left(\mathrm{m}^{3} / \mathrm{s}\right)$ for each basin for each time period. Note that variations in sediment yields between time periods cannot be accounted for by changes in annual river discharge. Overall, sediment flux displays a tighter cluster about the trend line for post-dam conditions because of reduction of peak floods caused by dam retention. Simulated correlation coefficients $\left(R^{2}\right)$ 

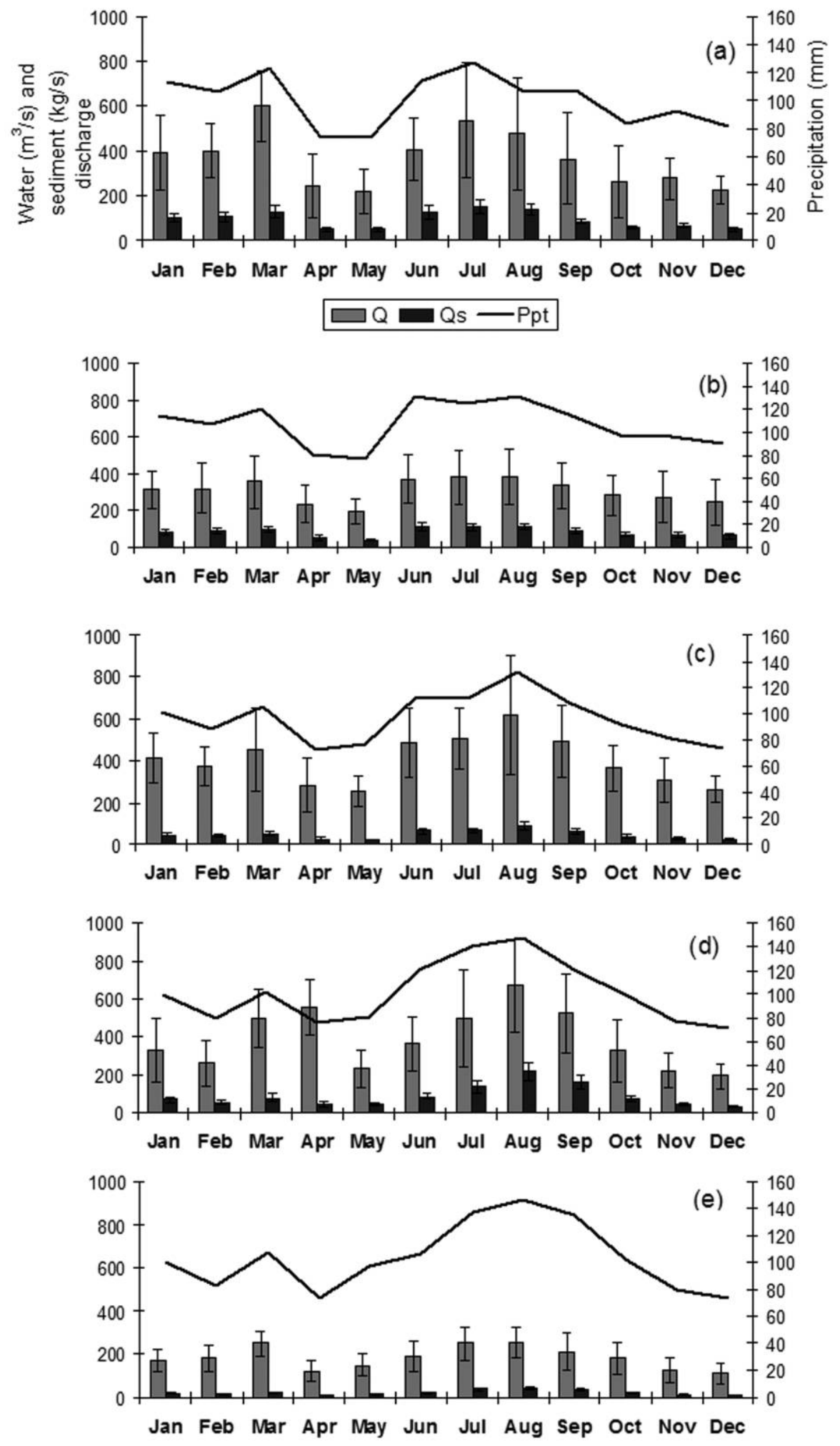

Figure 5. Annual variation of modeled sediment flux $(Q s)$, water discharge $(Q)$, and precipitation $(P p t)$, presented as monthly averages over 20 yr (1985-2005) for the Altamaha $(a)$, Savannah (b), Santee $(c)$, Pee Dee $(d)$, and Cape Fear (e) rivers. Note: sediment load values shown are multiplied by a factor of 2 . 

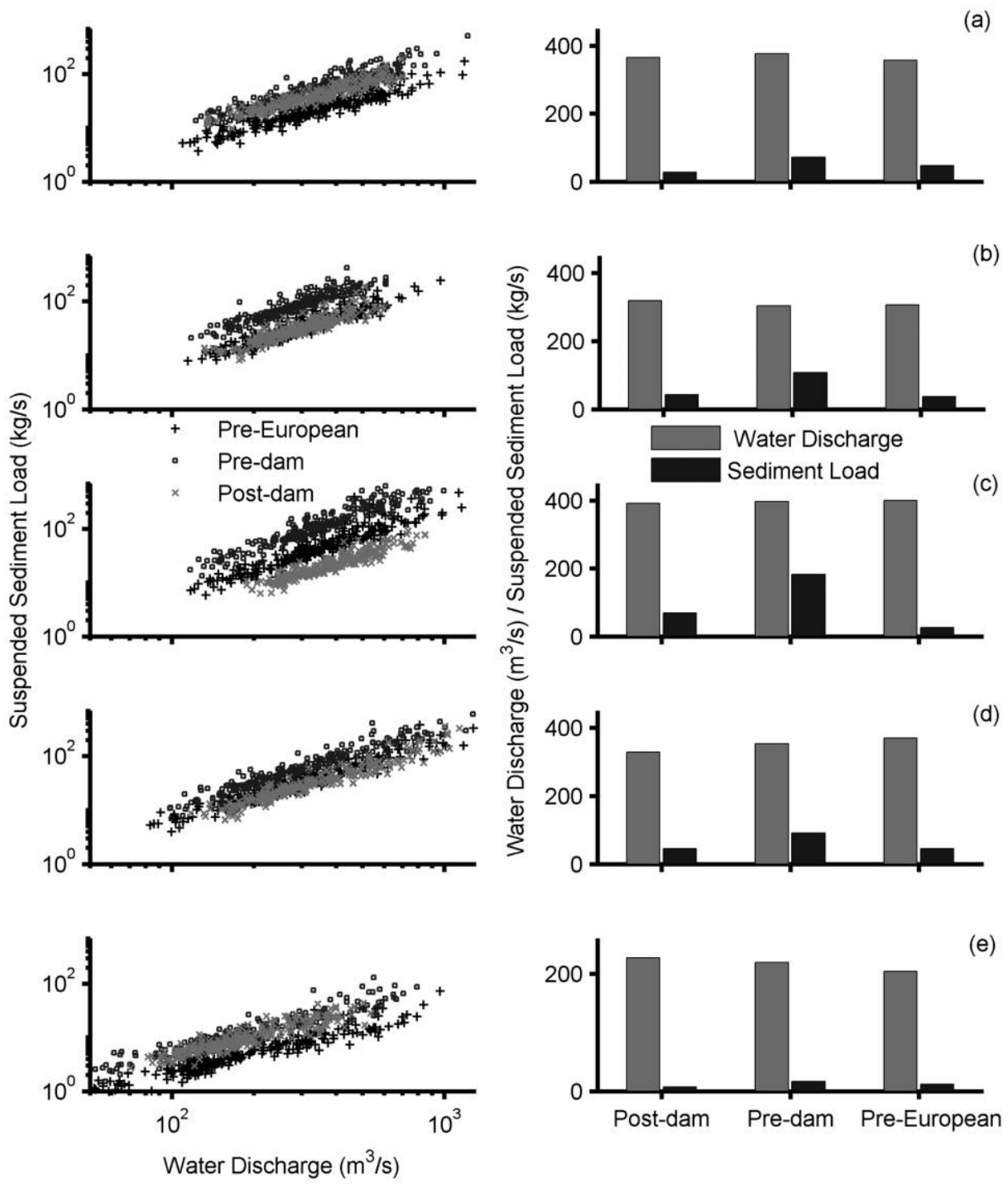

Figure 6. Left, log-log scatter plots of monthly mean suspended sediment load versus monthly mean water discharge for "pristine" (pre-European), pre-dam, and post-dam periods. Right, bar graphs of mean annual sediment yield (black) and water discharge (gray) for each period. Altamaha $(a)$, Savannah $(b)$, Santee $(c)$, Pee Dee $(d)$, and Cape Fear $(e)$ basins.

for suspended sediment load versus water discharge are $0.64,0.60$, and 0.70 for pre-European, pre-dam, and current (post-dam) conditions, respectively. Individual basin results are discussed below, scatter plots are shown in figure 6, and numerical values of the analyses are listed in table 4 .

Altamaha River. A relatively small percentage $(\sim 25 \%)$ of the basin is affected by reservoirs, and the farthest-downstream reservoir has a trapping efficiency of $92 \%$ (determined via the Brown [1943] equation). Annual peak floods, as predicted by HydroTrend on the basis of simulated water-rout- ing delays, have been reduced, on average, by $70 \%$; however, it is not uncommon for large dams to reduce average annual peak discharges by up to 90\% in some basins (Graf 2006).

Flux. Simulated sediment flux values are $1.5 \pm 0.2 \mathrm{Mt} / \mathrm{yr}$ for current conditions and $2.3 \pm$ $0.5 \mathrm{Mt} / \mathrm{yr}$ for pre-dam conditions, in good agreement with the published values of 1 and $2.5 \mathrm{Mt} /$ yr, respectively (Milliman and Farnsworth 2005; fig. 6a). The pre-European sediment load was moderately lower than the current load $(0.9 \pm 0.5 \mathrm{Mt} /$ yr).

Yield. Simulations under pre-European condi- 
tions produce a sediment yield (flux per unit area per unit time) of approximately $24 \pm 5.6 \mathrm{t} / \mathrm{km}^{2} / \mathrm{yr}$. Sediment yield increased by $\sim 160 \%$ during the time of peak erosive conditions and has since been reduced by $35 \%$.

Savannah River. The farthest-downstream reservoir has a trapping efficiency of $94 \%$, and simulations show that peak flood discharge has been reduced by up to $78 \%$ through reservoir retention.

Flux. Published suspended sediment load estimates before and after dam construction are 2.8 and $\sim 1 \mathrm{Mt} / \mathrm{yr}$, respectively (Milliman and Farnsworth 2005). Simulated sediment loads are $3.5 \pm 1.03$ and $1.1 \pm 0.24 \mathrm{Mt} / \mathrm{yr}$ for pre- and post-dam conditions, respectively. The pre-European sediment load was higher than the current load $(1.4 \pm 0.31 \mathrm{Mt} / \mathrm{yr}$; fig. $6 b)$.

Yield. Results indicate that the yield more than doubled, from $50 \pm 9.0$ to $128 \pm 38.3 \mathrm{t} / \mathrm{km}^{2} / \mathrm{yr}$, as a result of accelerated erosion. Under current conditions, annual yield is lower than that during preEuropean conditions $\left(\sim 43.5 \pm 5.5 \mathrm{t} / \mathrm{km}^{2} / \mathrm{yr}\right)$ because of extensive damming.

Santee River. Nearly the entire Santee River ba$\sin (85 \%)$ is under the influence of hydroelectric operation, and as early as 1976, damming and rediversion of the river had begun to alter the Santee River delta, the largest cuspate delta on the U.S. Atlantic coast, transforming it from a progradational- to a regressive-stage delta (Stephens et al. 1976).

Flux. Estimates for pre-dam conditions within the Santee basin are not available, and current sediment flux is estimated at $0.86 \mathrm{Mt} / \mathrm{yr}$ (Milliman and Farnsworth 2005). Modeled sediment fluxes are $0.81 \pm 0.1 \mathrm{Mt} / \mathrm{yr}$ for current conditions, $5.8 \pm 1.7$ $\mathrm{Mt} / \mathrm{yr}$ for accelerated erosive (i.e., pre-dam) conditions, and $2.24 \pm 0.97 \mathrm{Mt} / \mathrm{yr}$ for pre-European conditions (fig. 6c).

Yield. The normalized suspended sediment yield for the Santee basin has decreased more than that for any other basin $(\sim 86 \%)$ since the early 1900s. Yields today $\left(20 \pm 2.5 \mathrm{t} / \mathrm{km}^{2} / \mathrm{yr}\right)$ are significantly lower than they were under pre-European conditions $\left(56.3 \pm 24.4 \mathrm{t} / \mathrm{km}^{2} / \mathrm{yr}\right)$.

Pee Dee River. Gross sediment budgets have been estimated for the Pee Dee Basin by Patchineelam et al. (1999) on the basis of accretion rates in Mud Bay, and Phillips (1991) has constructed sediment budgets within the upper reaches of the river. This upper (Yadkin) portion is extensively dammed for flood control, as well as hydroelectric power, and approximately $20 \%$ of the uppermost basin is affected.

Flux. The published sediment load, estimated nearly $105 \mathrm{~km}$ upstream of the river mouth (USGS 02131000 ), is $0.5 \mathrm{Mt} / \mathrm{yr}$ for current conditions and $0.86 \mathrm{Mt} / \mathrm{yr}$ for pre-dam conditions (Milliman and Farnsworth 2005). These estimates do not reflect drainage from the Little Pee Dee River, a major tributary of the Pee Dee system, and include only $24,880 \mathrm{~km}^{2}$ of the total area $\left(47,560 \mathrm{~km}^{2}\right)$. Because our modeled results incorporate the entire Pee Dee Basin, simulated water discharge is greater $(\sim 40 \%)$ than the discharge measured at the specified gauging station, and similarly, suspended sediment flux is more than double the published value (1.45 \pm $0.3 \mathrm{Mt} / \mathrm{yr}$ ). Unlike the other study rivers, the majority of the Pee Dee Basin lies in the relatively flat Coastal Plain region, which contributes to a high storage capacity along its lower reach (Phillips 1991). Sediment sequestration due to floodplain storage is not parameterized in the BQART equation (eq. [4]); therefore, Kettner et al. (2010) recommend incorporating a conveyance loss for rivers where floodplain storage is significant. Phillips (1991) has applied a 60\% conveyance loss to colluvium/alluvium in North Carolina watersheds. If the same conveyance loss were applied to our results, current flux would be $0.6 \mathrm{Mt} / \mathrm{yr}$. Simulation results are $2.9 \pm 0.84 \mathrm{Mt} / \mathrm{yr}$ for accelerated soil conditions and $1.44 \pm 0.3 \mathrm{Mt} / \mathrm{yr}$ for pre-European conditions.

Yield. The current (1985-2005) suspended sediment yield is $\sim 30.5 \pm 6.5 \mathrm{t} / \mathrm{km}^{2} / \mathrm{yr}$. During peak soil erosion, yields were higher $\left(62 \pm 17 \mathrm{t} / \mathrm{km}^{2} / \mathrm{yr}\right)$; however, before European settlement, the sediment yield was nearly identical to that today $(\sim 30.4 \pm$ $7.5 \mathrm{t} / \mathrm{km}^{2} / \mathrm{yr}$ ). The consistency between pre-European and post-dam conditions supports the significance of downstream buffering as well as the potential of a large river to recover its sediment load downstream (Phillips 1991; Walling and Fang 2003; Phillips and Slattery 2006).

Cape Fear River. Approximately $16 \%$ of this small basin is modified by dam operation, and modeled results indicate that peak floods have been reduced by up to $69 \%$.

Flux. Pre-dam estimates of suspended sediment loads are not available, and present-day conditions are estimated to be $0.29 \mathrm{Mt} / \mathrm{yr}$ (Milliman and Farnsworth 2005). The simulated sediment flux is $0.37 \pm 0.06 \mathrm{Mt} / \mathrm{yr}$. Conditions are $0.54 \pm 0.14 \mathrm{Mt} /$ yr under peak soil acceleration conditions and $0.23 \pm 0.07 \mathrm{Mt} / \mathrm{yr}$ under pre-European conditions (fig. 6e). 
Yield. Normalized present-day yield estimates are $15.1 \pm 2.3 \mathrm{t} / \mathrm{km}^{2} / \mathrm{yr}$ over a 20 -yr period (19852005). During peak acceleration, yields were slightly higher, at $21.9 \pm 5.1 \mathrm{t} / \mathrm{km}^{2} / \mathrm{yr}$, and under pre-European conditions, the average yield was lower than it is today $\left(9.2 \pm 2.7 \mathrm{t} / \mathrm{km}^{2} /\right.$ year $)$.

Error Analysis. Four (canopy, evapotranspiration, subsurface storm flow, and groundwater pool) of the six parameters analyzed for sensitivity alter sediment flux through variations in discharge on a seasonal scale. They have little influence, however, over longer timescales, and changes in sediment flux were negligible $(<10 \mathrm{~kg} / \mathrm{s}$ over $20 \mathrm{yr})$ when these parameters were forced to maximum and minimum boundary conditions. The total error $\left(T_{\text {error }}\right)$ associated with anthropogenic $\left(E_{\mathrm{h}_{\text {error }}}\right)$ and lithologic $\left(L_{\text {error }}\right)$ variables was more significant, and using a standard error propagation equation (Taylor 1982) for summing errors of the same weight (eq. [6]), we found that the maximum potential error that could be introduced via the sum of these two parameters could alter results by up to $184 \%$ :

$$
T_{\text {error }}=\sqrt{\left(E_{\mathrm{h}_{\text {error }}}\right)^{2}+\left(L_{\text {error }}\right)^{2}} .
$$

In this study, however, lithology is known with moderately high confidence, so we removed this parameter and found that anthropogenic influence alone is capable of causing a maximum error of up to $60 \%$ in the long-term sediment flux results. This underlines the necessity of imposing realistic boundary conditions in the field of numerical modeling, and we are confident in the use of erosive land use (Trimble 1974) as a proxy for anthropogenic influence during the pre-dam era (Kettner et al. 2010).

\section{Discussion and Conclusions}

Results indicate that total sediment supply to the South Atlantic Bight coastal zone has decreased by approximately $55 \%$ since the placement of reservoirs. The mean annual suspended sediment load transfer rate was $6.2 \mathrm{Mt} / \mathrm{yr}$ under pre-European (1680-1700) conditions and 15.04 Mt/yr under predam (1905-1925) conditions and is $5.2 \mathrm{Mt} / \mathrm{yr}$ under current conditions. Overall, the rivers of the southeast are now transporting $1.0 \mathrm{Mt} / \mathrm{yr}$ (or 16\%) less sediment than they did during pre-European times. This is consistent with the findings of Syvitski et al. (2005), who estimated that North American rivers now transport, on average, 19\% less sediment than they did before European influence. At present, the Altamaha River, which is considered pris- tine in its lower reaches, and the Cape Fear River discharge slightly more sediment today than under conditions typical for the period before the arrival of Europeans, because of contemporary alteration of the land surface. The Savannah and Santee rivers, which are heavily modified through damming, discharge significantly less sediment, compared with pre-European fluxes. The flux of the Pee Dee River has not changed significantly, possibly because of a buffering effect downstream (Phillips and Slattery 2006; Walling 2006). Figure 7 provides a "snapshot" of sediment discharge over the three analyzed time periods, with arrow sizes proportional to sediment fluxes during the respective specific time periods.

Temporary Sediment Storage. The length of time that sediment may be stored within upstream hillslopes or downstream floodplains can vary between a few days and hundreds of years (Meade and Parker 1984; Phillips 1991). Trimble (1974) predicted that more than $90 \%$ of the $25 \mathrm{~km}^{3}$ of soil that was eroded from the uplands of the Piedmont has not reached the coast but is still in storage on hillslopes and in valleys (colluvium) within the Piedmont. Phillips (1991) showed that $68 \%$ of the total sediment produced within the Pee Dee watershed is stored as colluvium and that only a drastic increase in upstream erosion rates (e.g., European deforestation) would result in a corresponding change at the coast because of sediment storage within this large basin. Meade (1982) estimated that a significant portion of the eroded soil in the southeast is stored on flood plains (alluvium) along the coast. Alternatively, Renwick et al. (2005) suggested that too much emphasis has been placed on colluvial and alluvial storage and not enough on storage within impoundments in relation to upland erosion. HydroTrend does not account for short-term sediment accumulation within downstream reaches (Syvitski et al. 1998), possibly producing overestimated load results because alluvial buffering cannot be accounted for in large-scale studies (Walling and Fang 2003). Conversely, our results include the final distance from the gauging station to the sea, where more sediment has the potential to be added through tributaries, erosion from stream banks, and/or movement out of storage (Milliman and Meade 1983). These processes have the potential to cancel out significant net flux over the short term (Phillips 1991; Walling 2006). In addition, fundamental problems associated with comparing simulation results to observations from gauges located tens of kilometers upstream are well documented (Meade 1982; Milliman and Meade 1983; Phillips and Slattery 2006). These issues emphasize the need for increased sediment-monitor- 


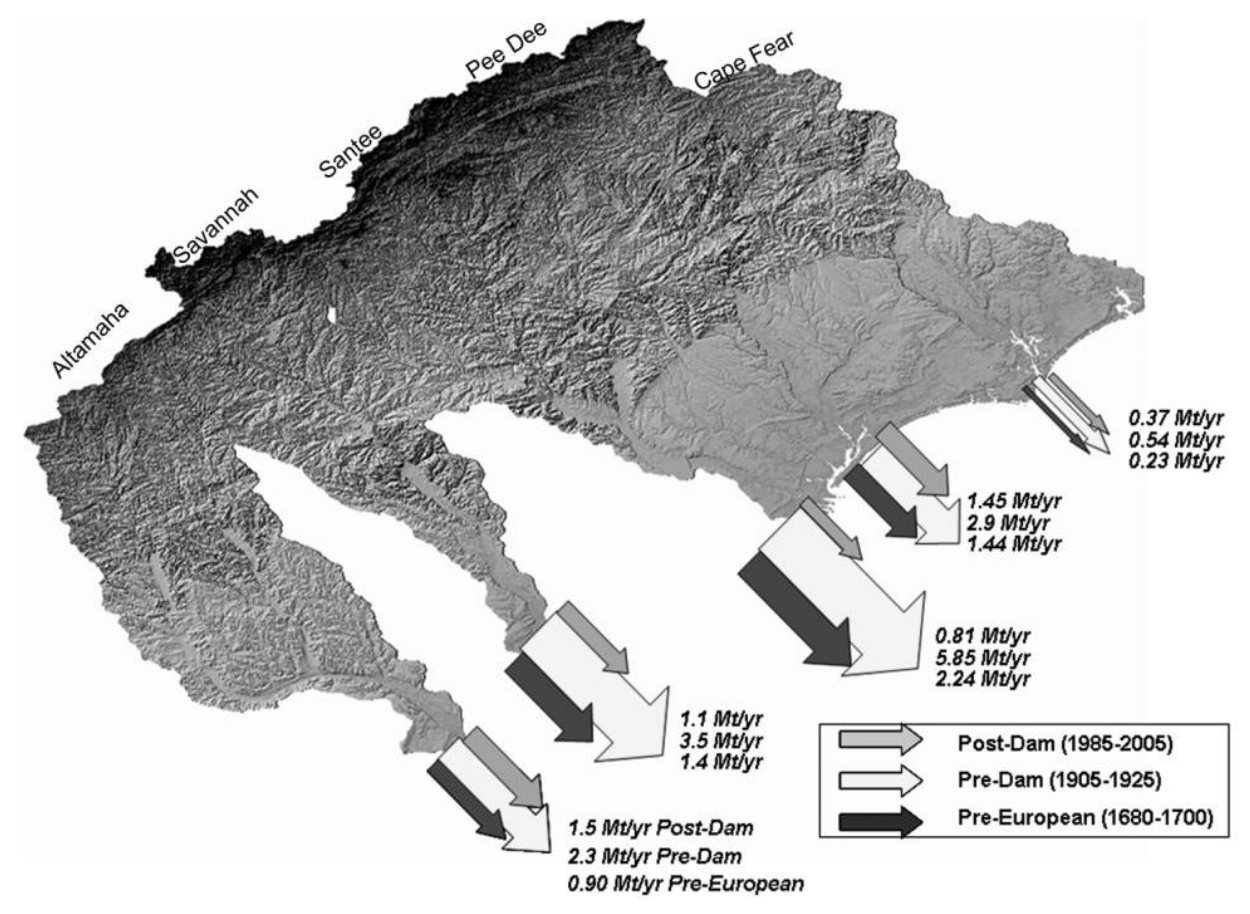

Figure 7. Relief map (50 $\times$ vertical exaggeration) of the five study basins indicating supply of sediment to the coastal zone, with scaled arrows over the three examined time periods.

ing programs and/or applications of appropriate numerical models, the latter of which is a goal of this study.

Implications for the Coastal Zone. Along much of the South Atlantic Bight, tidal inlets characterized by ebb-dominated flow help to form ebb shoals seaward of the inlets, which are the major source of sediment for the coastline (Morton and Miller 2005). Fluvial transfer of sediment is of secondary importance, and more likely the primary role of fluvial sediment is to help coastal marshes keep pace with sea level rise (e.g., Voulgaris and Meyers 2004; Murphy and Voulgaris 2006). However, it is believed that before the placement of dams, more sediment was available at the coastal zone than is now available and that it was transported into the nearshore zone, perhaps even contributing to budget stability at the coast (Hayes 1994). Furthermore, the inner continental shelf is covered with suborthoquartzitic fluvial sands, most likely brought to the coast by Piedmont rivers (Milliman et al. 1972).

Because of present-day coastal erosion in the southeast, more than 101 million cubic yards of sand have been added to the beaches of North Carolina, South Carolina, and Georgia, and a complete data set on project volumes has been compiled by Western Carolina University (Beach Nourishment Experience 2008). Morton and Miller (2005) com- piled a data set from more than 20,000 shoreline transects along the South Atlantic Bight that indicates a long-term erosional trend; however, their study points out an increase in erosion rates beginning in the 1960s and 1970s, which coincides with the period after peak reservoir construction in the Piedmont region. According to their study, maximum erosion rates have ranged up to $10 \mathrm{~m} / \mathrm{yr}$ from the end of the nineteenth century until today; however, maximum erosion rates from the time of dam emplacement until today are estimated at $\sim 34 \mathrm{~m} /$ yr (Morton and Miller 2005).

A definitive quantitative link between reservoir emplacement and coastal erosion is admittedly difficult to establish because of potential recovery downstream (Phillips and Slattery 2006) and the anthropogenic and natural dynamics of the fluvial and estuarine/coastal systems. Furthermore, the grade of sediment particles, which likely changed after emplacement of reservoirs, would have an effect on whether sediment becomes entrained easily for transport or becomes trapped. There is no doubt that sea level rise and other processes acting at the coast are certainly the main drivers of coastal erosion; however, the aforementioned link undoubtedly serves as a potential source for further research along the South Atlantic Bight. 
Concluding Remarks. Present-day simulated water and sediment discharge rates were verified by current field conditions, and new data sets for conditions under accelerated soil erosion and pristine conditions were presented. In summary, over a very short period of time, humans caused both a significant increase $(145 \%)$ and a decrease $(55 \%)$ in mean annual suspended sediment flux to the South Atlantic Bight region. Results indicate that the two rivers most affected by reservoir sediment retention (Santee and Savannah) are now discharging less sediment than they did before European settlement and that two other, less regulated basins (Altamaha and Cape Fear) are discharging slightly more. The Pee Dee River shows no significant change between the two time periods.

The HydroTrend model was chosen for this study because it can account for a large (regional) area, reservoir storage, and human impact. A major contribution of the model is its ability to simulate mean annual sediment discharge without observational data, which is invaluable in a science where very few data are collected or data are outdated or have been recycled with error (Milliman and Meade 1983). We conclude that using HydroTrend in the southeastern region is an appropriate application to this field of study, and our results support this. We are confident that HydroTrend can be applied to other watersheds of the southeastern region.

We believe that because of reservoir retention, modeled present-day sediment loads indicate a return to yields similar to those before European settlement, which echoes results from earlier work on the Chesapeake Basin by Pasternack et al. (2001). This is not to say that there has been a return to similar conditions or that accelerated soil erosion, especially in small upstream tributaries, has halted. Since most of the legacy sediment is thought to be in storage within the Piedmont (Trimble 1974; Phillips 1991), dams located on the fall line and below have the potential to capture this legacy sediment. In turn, we acknowledge that sediment moving out of storage downstream of the dams has the potential to offset the stored sediment upstream. This is documented by Phillips and Slattery (2006) on the Trinity River in Texas, and we believe this to be the case in the Pee Dee watershed. Furthermore, trapping efficiency will decrease as reservoirs fill with sediment, a process that occurs at different rates for all reservoirs, depending on reservoir morphology, the number of floods occurring in the watershed per year, and sediment input, among other factors. As stated by the World Commission on Dams (2000), any reservoir, large or small, is typically reduced in capacity by $0.5 \%-1 \%$ each year. We performed a back-of-the-envelope calculation, assuming a $1 \%$ infill rate and using the year of construction for each of the dams in this study, and found that the projected infill time for the dams of this study varies between 12 and $64 \mathrm{yr}$, with a simple mean of $39 \mathrm{yr}$.

In conclusion, we acknowledge the significant imbalance between basin production and basin yield due to source/sink time lags and buffering (Phillips and Slattery 2006; Walling 2006). However, we suggest that the southeastern coastal region should be watched closely in the coming decades as dams continue to capture legacy sediment as well as present-day eroded soil.

\section{A C K N O W LE D G M E N T S}

K. McCarney-Castle was supported by a National Science Foundation (NSF) GK-12 fellowship and a Department of Education fellowship under the Graduate Assistance in Areas of National Need (GAAN) grant to the University of South Carolina. Partial support for G. Voulgaris was obtained from the National Science Foundation (NSF awards OCE-0451989 and OCE-0535893).

\section{REFERENCES CITED}

Beach Nourishment Experience. 2008. Western Carolina University Program for the Study of Developed Shorelines, http://psds.wcu.edu/1038.asp (accessed September 15, 2008).

Brown, C. B. 1943. Discussion of sedimentation in reservoirs by J. Witzig. Proc. Am. Soc. Civ. Eng. 69:14931500.

Brune, G. M. 1953. Trap efficiency of reservoirs. Trans. Am. Geophys. Union 34:407-418.

Curtis, W. F.; Culbertson, J. K.; and Chase, E. B. 1973.
Fluvial-sediment discharge to the oceans from the conterminous United States. U.S. Geol. Surv. Circ. 670:1-17.

Dole, R. B., and Stabler, H. 1909. Denudation. U.S. Geol. Surv. Water Supply Pap. 234:78-93.

EPA (U.S. Environmental Protection Agency). 2000. National Water Quality Inventory Report, http://www .epa.gov/305b/2000report/ (accessed October 16, 2008).

Farnsworth, K. L., and Milliman, J. D. 2003. Effects of 
climatic and anthropogenic change on small mountainous rivers: the Salinas River example. Global Planet. Change 39:53-64.

Fournier, F. 1960. Climat et érosion: la relation entre l'érosion du sol par l'eau et des précipitations atmosphériques. Paris, Presses Universitaires de France, $201 \mathrm{p}$.

Graf, W. L. 2006. Downstream hydrologic and geomorphic effects of large dams on American rivers. Geomorphology 79:336-360.

Gregory, K. J. 2006. The human role in changing river channels. Geomorphology 79:172-191.

Hadley, R. F.; Lal, R.; Onstand, C. A.; Walling, D. E.; and Yair, A. 1985. Recent developments in erosion and sediment yield studies. Paris, International Hydrological Programme, UNESCO.

Hayes, M. O. 1994. The Georgia Bight barrier system. In Davis, R. A., Jr., ed. Geology of Holocene barrier island systems. New York, Springer, p. 233-304.

James, L. A. Forthcoming. Sediment waves, bed waves, legacy sediment, and hydraulic myopia. Geogr. Compass.

Jansen, J. M. L., and Painter, R. G. 1974. Predicting sediment yield from climate and topography. J. Hydrol. 21:371-380.

Kettner, A. J.; Gomez, B.; and Syvitski, J. P. M. 2007. Modeling suspended sediment discharge from the Waipaoa River system, New Zealand: the last 3000 years. Water Resour. Res. 43:W07411, doi:10.1029/ 2006WR005570.

Kettner, A. J.; Restrepo, J. D.; and Syvitski, J. P. M. 2010. A spatial simulation experiment to replicate fluvial sediment fluxes within the Magdalena River Basin, Colombia. J. Geol. 118:363-379.

Kettner, A. J., and Syvitski, J. P. M. 2008a. HydroTrend v.3.0: a climate-driven hydrological transport model that simulates discharge and sediment load leaving a river system. Comput. Geosci. 34:1170-1183.

- 2008b. Predicting discharge and sediment flux of the Po River, Italy since the Last Glacial Maximum. In de Boer, P. L.; Postma, G.; Van der Zwan, C. J.; Burgess, P. M.; and Kukla, P., eds. Analogue and numerical forward modeling of sedimentary systems: from understanding to prediction. Int. Assoc. Sedimentol. Spec. Publ. 39:171-190.

Kondolf, G. M. 1997. Hungry water: effects of dams and gravel mining on river channels. Environmental Management 21:533-551.

Leopold, L. B., and Maddock, T. 1953. The hydraulic geometry of stream channels and some physiographic implications. U. S. Geol. Surv. Prof. Pap. 252.

Liquete, C.; Canals, M.; Arnau, P.; Urgeles, R.; and Durrieu de Madron, X. 2004. The impact of humans on strata formation along the Mediterranean margins. Oceanography 17:70-80.

Ludwig, W., and Probst, J.-L. 1998. River sediment discharge to the oceans: present-day controls and global budgets. Am. J. Sci. 298:265-295.
Meade, R. H. 1982. Sources, sinks, and storage of river sediments in the Atlantic drainage of the United States. J. Geol. 90:235-252.

Meade, R. H., and Parker, R. S. 1984. Sediment in rivers of the United States. U.S. Geol. Surv. Water Pap. 2275: 49-60.

Meade, R. H., and Trimble, S. W. 1974. Changes in sediment loads in rivers of the Atlantic drainage of the United States since 1900. In Effects of man on the interface of the hydrological cycle with the physical environment. Int. Assoc. Hydrol. Sci. Publ. 113:99104.

Meade, R. H.; Yuzyk, T. R.; and Day, T. J. 1990. Movement and storage of sediment in rivers of the United States and Canada. In Wolman, M. G., and Riggs H. C., eds. Surface water hydrology (Geology of North America, Vol. O-1). Boulder, CO, Geol. Soc. Am., p. 255-280.

Milliman, J. D. and Farnsworth, K. L. 2005. River runoff, erosion and delivery to the coastal ocean: a global analysis. Cambridge, Cambridge University Press.

Milliman, J. D., and Meade, R. H. 1983. World-wide delivery of river sediments to the oceans. J. Geol. 91:121.

Milliman, J. D.; Pilkey, O. H.; and Ross, D. A. 1972. Sediments of the continental margin off the eastern United States. Geol. Soc. Am. Bull. 83:1315-1334.

Milliman, J. D., and Syvitski, J. P. M. 1992. Geomorphic/ tectonic control of sediment discharge to the ocean: the importance of small mountainous rivers. J. Geol. 100:525-544.

Morehead, M. D.; Syvitski, J. P. M.; Hutton, E. W. H.; and Peckham, S. D. 2003. Modeling the temporal variability in the flux of sediment from ungauged river basins. Glob. Planet. Change 39:95-110.

Morton, R. A., and Miller, T. L. 2005. National assessment of shoreline changes, pt. 2. Historical shoreline changes and associated coastal land loss along the U. S. southeast Atlantic Coast U.S. Geol. Surv. Open-File Rep. 2005-1401.

Murphy, S., and Voulgaris, G. 2006. A study of the role of tides, rainfall and seasonality in marsh sedimentation from long-term suspended sediment concentration data: North Inlet, South Carolina. Mar. Geol. 227:31-50.

Overeem, I.; Syvitski, J. P. M.; Hutton, E. W. H.; and Kettner, A. J. 2005. Stratigraphic variability due to uncertainty in model boundary conditions: a casestudy of New Jersey shelf over the last 40,000 years. Mar. Geol. 224:23-41.

Panin, A. 2004. Land-ocean sediment transfer in palaeotimes and implications for present-day natural fluvial fluxes. In Golosov, V.; Belyaev, V.; and Walling, D. E., eds. Sediment transfer through the fluvial system: proceedings of a symposium held in Moscow, August 2004. Int. Assoc. Hydrol. Sci. Publ. 288:115-124.

Pasternack, G. B.; Brush, G. S.; and Hilgartner, W. B. 2001. Impact of historic land-use change on sediment 
delivery to a Chesapeake Bay subestuarine delta. Earth Surf. Process. Landf. 26:409-427.

Patchineelam, S. M.; Kjerfve, B.; and Gardner, L. R. 1999. A preliminary sediment budget for the Winyah Bay estuary, South Carolina, USA. Mar. Geol. 162:133144.

Phillips, J. D. 1991. Fluvial sediment delivery to a Coastal Plain estuary in the Atlantic drainage basin of the United States. Mar. Geol. 98:121-134.

Phillips, J. D., and Slattery, M. C. 2006. Sediment storage, sea level, and sediment delivery to the ocean by coastal plain rivers. Prog. Phys. Geogr. 4:513-530.

Purvis, J. C. 2006. Pan evaporation records for the South Carolina area. Department of Natural Resources, South Carolina State Climatology Office, http:// www.dnr.sc.gov/climate/sco/Publications/pan_evap _records.php (accessed December 1, 2008).

Renwick, W. H.; Smith, S. V.; Bartley, J. D.; and Buddemeier, R. W. 2005. The role of impoundments in the sediment budget of the conterminous United States. Geomorphology 71:99-111.

Stahle, D. W., and Cleaveland, M. K. 1992. Reconstruction and analysis of rainfall over the southeastern U.S.A. for the past 1000 years. Bull. Am. Meteorol. Soc. 73:1947-1961.

Stephens, D. S.; Van Nieuwenhuise, D. S.; Mullin, P.; Lee, C.; and Kanes, W. H. 1976. Destructive phase of deltaic development: North Santee River delta. J. Sediment. Res. 46:132-144.

Syvitski, J. P. M. 2003. Supply and flux of sediment along hydrological pathways: research for the 21 st century. Glob. Planet. Change 39:1-11.

Syvitski, J. P. M.; Kettner, A. J.; Peckham, S. D.; and Kao, S. 2004. Predicting the flux of sediment to the coastal zone: application to the Lanyang watershed, northern Taiwan. J. Coast. Res. 21:580-587.

Syvitski, J. P. M., and Milliman, J. D. 2007. Geology, geography, and humans battle for dominance over the delivery of fluvial sediment to the coastal ocean. J. Geol. 115:1-19.

Syvitski, J. P., and Morehead, M. D. 1999. Estimating river-sediment discharge to the ocean: application to the Eel margin, northern California. Mar. Geol. 154: $13-28$.

Syvitski, J. P.; Morehead, M. D.; and Nicholson, M. 1998. Hydrotrend: a climate-driven hydrologic-transport model for predicting discharge and sediment load to lakes or oceans. Comput. Geosci. 24:51-68.
Syvitski, J. P. M.; Vörösmarty, C. J.; Kettner, A. J.; and Green, P. 2005. Impact of humans on the flux of terrestrial sediment to the global coastal ocean. Science 308:376-380.

Taylor, J. R. 1982. An introduction to error analysis: the study of uncertainties in physical measurements. Mill Valley, CA, University Science Books, 304 p.

Trimble, S. W. 1974. Man-induced soil erosion on the southern Piedmont 1700-1970. Ankeny, IA, Soil Conservation Society of America, $180 \mathrm{p}$.

Vörösmarty, C. J.; Meybeck, M.; Fekete, G. B.; and Sharma, K. 1997. The potential of neo-Castorization on sediment transport by the global network of rivers. In Walling, D. E., and Probst, J.-L., eds. Human impact on erosion and sedimentation. Int. Assoc. Hydrol. Sci. Publ. 245:261-273.

Vörösmarty, C. J.; Meybeck, M.; Fekete, B.; Sharma, K.; Green, P.; and Syvitski, J. P. M. 2003. Anthropogenic sediment retention: major global impact from registered river impoundments. Glob. Planet. Change 39: 169-190.

Vörösmarty, C. J.; Syvitski, J. P. M.; Day, J.; de Sherbinin, A.; Giosan, L.; and Paola, C. 2009. Battling to save the world's river deltas. Bull. At. Sci. 65:31-42, doi: $10.2968 / 065002005$.

Voulgaris, G., and Meyers, S. T. 2004. Net effect of rainfall activity on salt-marsh sediment distribution. Mar. Geol. 207:115-129.

Walling, D. E. 2006. Human impact on land-ocean sediment transfer by the world's rivers. Geomorphology 79:192-216.

Walling, D. E., and Fang, D. 2003. Recent trends in the suspended sediment loads of the world's rivers. Glob. Planet. Change 39:111-126.

Williams, G. P., and Wolman, M. G. 1984. Downstream effects of dams on alluvial rivers. U.S. Geol. Surv. Prof. Pap. 1286, 65 p.

Wilkinson, B. H. 2005. Humans as geologic agents: a deep-time perspective. Geology 33:161-164.

Willis, C. M., and Griggs, G. B. 2003. Reductions in fluvial sediment discharge by coastal dams in California and implications for beach sustainability. J. Geol. 111: 167-182.

World Commission on Dams. 2000. Dams and development, a new framework for decision-making. London, Earthscan, 356 pp. 